\title{
漢方医学基礎教育における医療薬学体験チーム型実習の導入と評価
}

\author{
日置智津子, ${ }^{*}$ 荒井勝彦, 高士将典, 新井 信
}

\section{Development and Evaluation of Fundamental Education about Kampo Medicine Adopting an Experimental Program in Clinical Pharmacy Using Team-based Format}

\author{
Chizuko Hioki, ${ }^{*}$ Katsuhiko ARAI, Masanori TAKASHI, and Makoto ARAI \\ Department of Oriental Medicine, Tokai University School of Medicine, \\ 143 Shimokasuya, Isehara City 259-1193, Japan
}

(Received April 16, 2008; Accepted July 1, 2008)

\begin{abstract}
A model core curriculum was proposed by the government in 2001 that outlined the core structure for undergraduate medical education, in which a Kampo medicine educational program was established. The following year, it was introduced in pharmacy as well as medicine. For fourth-year students at Tokai Medical University, a lecture on Kampo herbal medicine, focusing on clinical pharmacy, was given using team- based learning. Students learned the fundamental mechanism of Kampo medicine through team discussions about their subjective assessment of herbal medicine "Keishito" using their sensory organs and comparing objective analysis data of the main ingredients of Cinnamomi Cortex. They found that knowledge about Kampo medicine can come not only from clinical trials but also from objective observation. Through this educational program, almost all had an increased interest in the possible therapeutic value of herbal medicine. The results of examinations on Kampo herbal medicine showed that this program motivated students, especially those who had less or little interest in Kampo medicine before the lecture. The lecture-style team-based format could also facilitate a mutually supportive atmosphere, because negative feelings and concerns regarding initial traditional medicine can freely be expressed. In future, pharmacists as medical staff will provide preventive and curative primary care; since, for example, the Japanese government is pressing forward to prevent metabolic syndrome, which is related to lifestyle, this project could not have been completed without the cooperation of health professionals such as pharmacists. The present educational program in Kampo medicine may also be recommended for clinical pharmacy education.
\end{abstract}

Key words — Kampo medicine; team-based format; clinical pharmacy; model core curriculum

緒言

薬学 6 年制導入とともに医療法が改正された. 2006 年, 調剤を実施する薬局が医療提供施設とし て位置付けられ，OTC 薬（市販の一般用医薬品） に移行する保険適用薬の数も増えた。漢方薬につい ても一般用漢方製剂汎用の兆しがある。これは細分 化された西洋医学体系では対処できない自覚所見や 不定愁訴が多い疾病に, 漢方の効用が期待される傾 向と考えられる。1996 年の小柴胡湯による間質性 肺炎の死亡例報告を背景に, 漢方医学基礎教育の充 実が求められ，2001 年には医学や薬学（2002 年） 教育モデル・コアカリキュラムに漢方医学教育が盛

東海大学医学部東洋医学講座

*e-mail: chioki@is.icc.u-tokai.ac.jp
り込まれた. ${ }^{1)}$ 現在, 漢方医学教育は急速に進めら れ2,3) 学生用テキストも作成される中, ${ }^{4}$ 全国 80 大 学医学部, 医科大学で取り入れられている. しかし 教育時間数は大学により各様で, 教員不足という状 況の下, 代替医療の 1 つに組み込む医科大学もあ る. 東海大学医学部では 2003 年度から東洋医学の 講義が始まり(選択講義 18 時間), 2005 年度, 常勤 漢方専門医による外来診療開始に伴い，実臨床に漢 方を生かせる医師を育てるため東洋医学モデル・コ アカリキュラムの一般目標と到達目標（Table 1) を設定した。 2006 年には選択必修講義を 3 年生以 上を対象に 9 時間, 4 年生以上に 9 時間, さらに 1 学年全員を対象とした医学入門で 1 時間, 4 年生必 修講義 3 時間と増やす中で, 教育内容や教育技法に ついて研究を始めた。 2007 年度からは，さらに漢 
Table 1. Kampo Medicine Educational Goals

「一般目標」

東洋医学の基本的概念を習得する.

(東洋医学と西洋医学を融合させることで, 全人的医療 の視点に立った治療方針を選ぶことができる)

「到達目標」

1. 東洋医学と西洋医学の基本的概念の違い

2. 漢方と相補代替医療 (CAM), 民間療法の違い

3. 漢方の基本的概念（陰陽，虚実，寒熱，表裏，気血 水, 六病位, 五臓）「証」の概念を理解し，随証治 療について漢方の診断方法（望診, 聞診, 問診, 切 診）を経験

4. 漢方方剤の主な副作用および禁忌事項

方診療，鍼众，漢方生薬の実習講義を増やすことが できた.

現代臨床で漢方薬が有効かつ安全に活用されるに は, 客観的な西洋医学臨床研究による漢方薬の有効 性が解説され，EBM が実行されねばならない。し かし西洋薬と異なり漢方薬は原料生薬の採取時期や 産地, 加工法により，その成分系は微妙に異な る. ${ }^{5)}$ 複数成分で構成される漢方薬の特質は複雑な 上，主観的漢方理論体系（証）に即して適応症が決 められる．漢方医学は患者の背景を探りながら五感 を用いて観察し, 漢方理論体系に従って施療が進め られ，西洋医学では不足しがちな全人的医療遂行を 目標としている，東洋医学における EBM 構築は同 じ証の被験者を集約させるなど，西洋医学とは異な る視点が必要であり, ${ }^{6}$ 現代医療で漢方が活用され るには両者の特徵や共通点を理解することが重要と 考えられる。そこで 4 学年の必修講義の中に漢方生 薬実習 9 時間が取り入れられた。

この実習は漢方薬を薬化学解析と視覚, 味覚, 触 覚, 嗅覚の主観性の両面からみる内容であり, 処方 の仕方や調製を経験し，服用することで施療者，患 者双方の立場から漢方薬とはどのようなものかを探 索する。このような臨床に根差した医療薬学的体験 学習が，初学者に漢方勉学に対する意欲を起こさせ ることを目的とした，漢方を嫌う学生や，初めて経 験する学生が積極的に参加できるようチームを組ん だ. 7) 討論する過程で他者との違いや共感を経験し 漢方薬の長所，短所を考える機会を与えた．試験成 績と漢方薬に対する実習前後における漢方薬に対す る意識変化の調査から，本実習を通じて関心度の低
かった学生も漢方薬に興味を示し，モチベーション が高められたと推察された。

漢方医学教育は西洋医学教育に伴走するように進 められる. 西洋医学だけでは不足しがちな全人的医 療遂行を目標としている。しかし高度化した西洋医 学の医療現場で, 社会構造が複雑になるにつれて多 くの医療専門家の参画なくして全人的医療は達成で きない．薬剤師が医師に伴走するように非侵襲的に 患者を診断し，専門医学に秀でた医師や患者に総合 的な知識から得た疾病予防策や治療方法を提供でき れば，薬剤師は市民に信頼される全人的医療の提供 者になり得ると考える。

医療薬学体験チーム型実習は薬剂師育成にも応用 できると考えられたので報告する.

\section{対象と方 法}

東海大学医学部第 4 学年 116 名に漢方基礎理論の 総合講義 6 時間ののち，13 又は 14 人を 1 群として 少人数制 ${ }^{8}$ による漢方生薬，鍼尒，漢方理論の実習 を各 9 時間実施した。学生は漢方基礎理論で自分の 証を学習し，鍼众では鍼众師の指導の下に，つぼに 鍼を打つ体験をした。

漢方生薬実習は Table 2 に記したテキスト概要の 流れに従い，学生が漢方薬を正しく理解して学習意 欲を高めることを目的とした。 1 群を 2 チームに分 け，チーム単位で助け合いながら実習と発言を進め る方法を取った。

学習対象生薬は桂皮とし, 実習課題方剂は五苓散 （沢瀉，白术，猪苓，获苓，桂皮）と桂枝湯（桂皮, 苟薬，大雵，甘草，生姜）とした。五苓散は味や匂 い，外観や飲み易さ，効果を市販のエキス剂と生薬 散剤で比較させた。桂枝湯は 1 . ベトナム イエン バイ産 I 級桂皮，2. ベトナム イエンバイ産桂通 桂皮，3. 広南桂皮の中から無作為に選択し調製を 経験し，食用のセイロン産桂皮を対照として生薬及 びそれぞれを用いた桂枝湯の匂いや味，色や飲んだ あとの感覚の違いについて検討させた（Fig. 1). 薬効評価についてはテキストに記載した処方解説 （Table 3）を参考に，学生がそれぞれ自分の心身状 態を観察して判断しチームで検討をした。評価結果 を Fig. 2 に示したチャートに記させたのちに，各 桂皮のクマリン，精油成分，ケイヒアルデヒドの含 有量の測定結果（クマリン，ケイヒアルデヒド : 液 
Table 2. Contents of Textbook for the Practice

実習テキスト概要（実習の流れ）

序章 漢方による治療とは

$\S 1$ 身近な食べ物の中の生薬（薬食同源）

要点 味わう (味覚) ・におう (嗅覚) ・見て (視覚) ・ 触れて (触角) 感じる.

$\S 2$ 薬としての生薬

検討課題

1 食用ではなく, 薬として使用される生薬に求められる条件は?

2 人間の感覚 (味覚, 嗅覚, 視覚, 触覚) を使って効く薬を探れるか?

$\S 3$ 近代医学的治療における保険薬としての生薬

要点

1 西洋薬（単味薬剂）と同様, 安定した薬効, 安全性, 使用法が求められる.

2 近年, 薬理実験により, 漢方薬も薬効や作用機序が解明されつつある.

3 主要薬効成分の定量分析も可能になった.

自分の感覚による薬効評価と分析結果を比べる.

検討課題

§1〜3 を通じて漢方薬（生薬）の特徵や問題点を考える.

$\S 4$ 国際社会が着目する生薬：reference materials are attached

要点

生薬は, 多成分系の薬である. 漢方方剂や生薬単位で, 薬効解明が進められ新たな臨床展開が国際的に期待されている.

桂皮の 2 型糖尿病に対する効果について報告されており, 増加の一途をたどる生活習慣病や糖尿病などへの応用展開に向

け, 薬理研究や開発が西洋諸国でも進められている.

The program and lecture points in Kampo herbal medicine are shown.
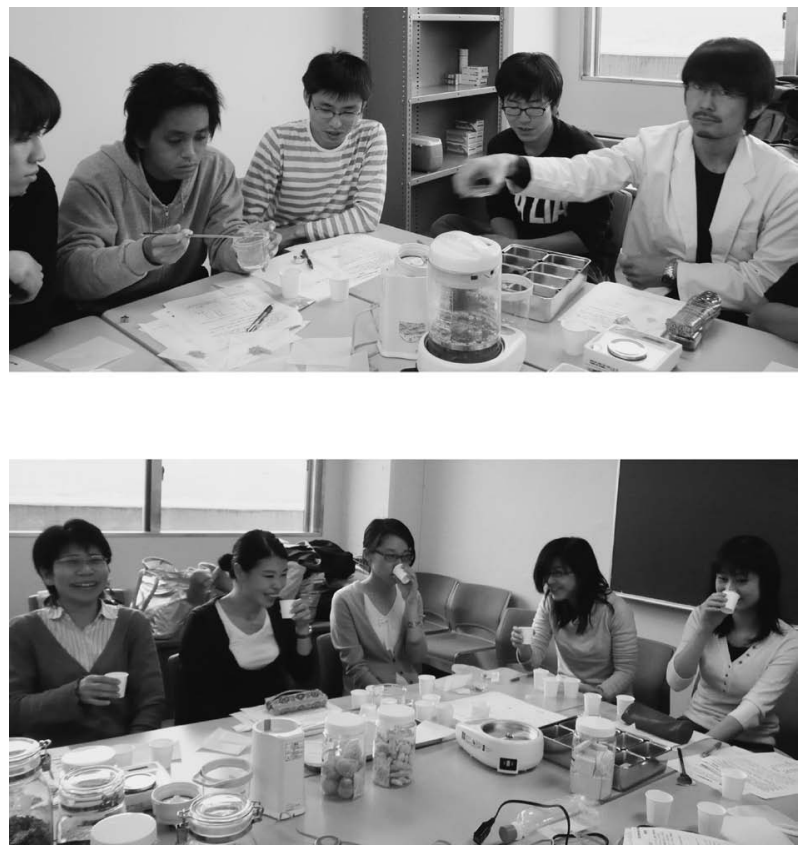

Fig. 1. Students Experienced Preparations and Taking the Herbal Medicines, and Discussed on Their Herbal Medicine with Teamwork

体クロマトグラフ法, 精油成分 : 日局法に従い測定, $n=6$; 一元配置分散分析の後 Scheffe 法により検 定）を提示した。主観的判断による結果と測定結果
を比較し成分系と味や匂い, 感性との相関や効果, 漢方薬についての考察などチームで討論させた.

\section{実習講義の評価法}

A グループ（6チーム，合計 40 名; 女 13 名, 男 27 名）は実習受講 2 日後に, B グループ（12 チー 厶, 合計 76 名 ; 女 32 名, 男 44 名）は実習受講前 に漢方医学基礎試験を受けた。試験内容は, 実習講 義内容と重複することなく, 100 点満点のうち 50 点を生薬と漢方薬の薬効や副作用に関する選択問題 とした.

漢方及び漢方薬に対する関心度や，将来における 展望について実習講義の前後で調査をした，講義前 後の漢方医学に対する関心度には paired $t$-test を用 いて解析し，成績と関心度の相関関係は Peasonの 相関係数を求めた.

\section{結果}

\section{1. 桂枝湯に対する主観的評価と成分含有量比較}

Figure 2 は桂枝湯を煎じ器（ニューマイコン漢 方煎じ器)を用いて調製した後, チーム毎に甘さ, 辛さ, 香りの強さ, 服用後に感じる体の温もり（室 温 21 度), 好み, 効果に対する期待度について 5 段 
Table 3. The Explanation on Appropriate Use and Effects of Keishito in the Textbook for Practice

\begin{tabular}{|c|c|}
\hline & 漢方方剂の処方解説 \\
\hline $\begin{array}{l}\text { 【使用目標 }(\text { 証 }) 】 \text { 比較的体力が低 } \\
\text { 下した人の熱性疾患急性期症状, } \\
\text { および慢性期疾患に用いるここが } \\
\text { できる. (悪寒や自然発汗を伴う発 } \\
\text { 熱, のぼせ, 四肢痛, 腹痛などが } \\
\text { 観察される) 腹部は腹力が弱く, } \\
\text { 軽度に腹直筋の緊張を認めること } \\
\text { がある. 脈は浮弱 (容易に触知で } \\
\text { き, 緊張力がそしい) の場合が多 } \\
\text { い. } \\
\text { 【応用疾患や症状】かぜ症候群 (発 } \\
\text { 熱, 頭痛など体力低下時のかぜの } \\
\text { 症状), 神経痛, 自律神経失調症, } \\
\text { 胃腸型感冒, 筋肉痛など. }\end{array}$ & $\begin{array}{c}\text { Rp. 桂枝湯 } \\
\text { 桂皮 } 4.0 \mathrm{~g} \\
\text { 苟薬 } 4.0 \mathrm{~g} \\
\text { 大霖 } 4.0 \mathrm{~g} \\
\text { 甘草 } 2.0 \mathrm{~g} \\
\text { 生姜 } 1.5 \mathrm{~g}\end{array}$ \\
\hline 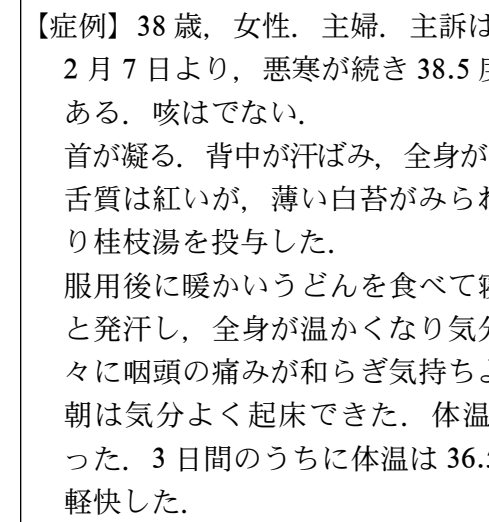 & 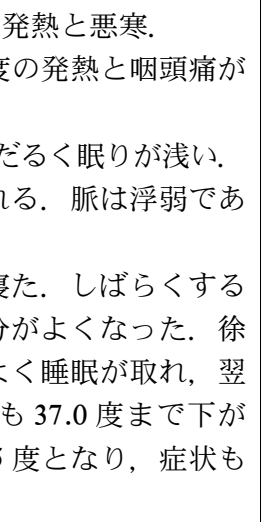 \\
\hline
\end{tabular}

Students took Keishito and guessed the efficacy via reading this content in textbook.

階評価を試みた結果である。桂枝湯は皮膚における 血流改善や体内の冷えを解消し, 内臟機能低下を改 善することを説明した。効果予測は，風邪の初期症 状，胃の痛みや膨満感，もたれ，体表の冷えなどに 改善が期待できるかを服用後の体感から予測するこ とにした（Table 3). Figure 2(a)，(b)，(c)にみら れるように各グループで評価が異なったことから, 同じ湯剤であっても個人によって感じ方や，効果の 評価が異なることに疑問と驚きを発した学生が多か った。「同じ人でも体調によって評価は違うと思 う」，「自分が医師であれば，気力や体力が弱い患者 に処方しようと思う」など患者の状況を考え，医師 になった自分を想定した意見もあった。1 チーム （116 名）の平均值を Fig. 2(d)に示した。各桂皮中 のクマリン含有量（平均值土標準偏差値）は I 級桂
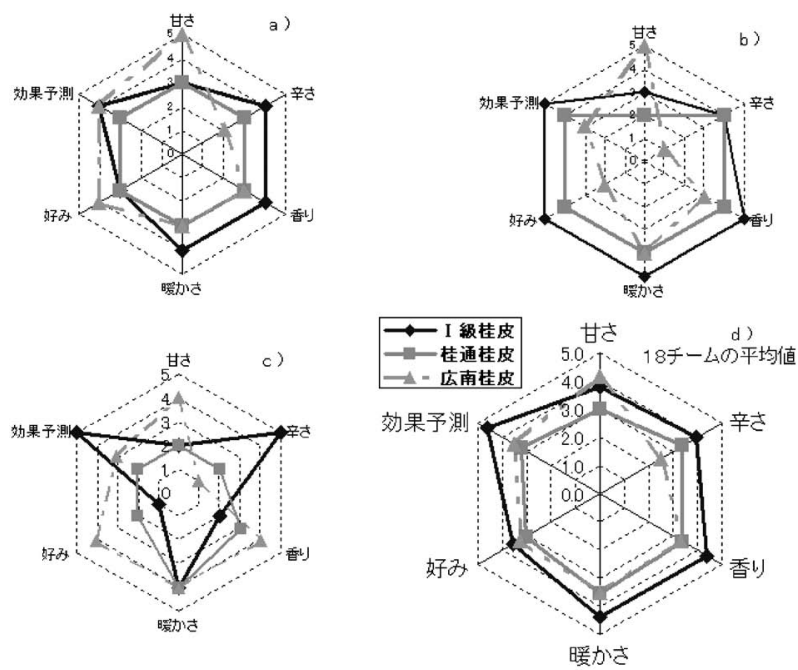

d) 18 チームの平均点 (平均値士標準偏差)

\begin{tabular}{rcccccc} 
& 甘さ & 辛さ & 香り & 暖かさ & 好み & 効果予測 \\
\hline I 級桂皮 & $3.7 \pm 1.2$ & $3.9 \pm 0.9$ & $4.4 \pm 0.8$ & $4.4 \pm 0.8$ & $3.6 \pm 1.3$ & $4.6 \pm 0.6$ \\
桂通桂皮 & $3.0 \pm 0.7$ & $3.3 \pm 0.9$ & $3.4 \pm 0.7$ & $3.5 \pm 0.7$ & $3.0 \pm 0.9$ & $3.2 \pm 0.8$ \\
広南桂皮 & $4.2 \pm 0.9$ & $2.5 \pm 1.3$ & $3.3 \pm 0.9$ & $3.5 \pm 0.9$ & $3.3 \pm 1.1$ & $3.5 \pm 0.7$ \\
\hline
\end{tabular}

Fig. 2. Assessment of Three Kinds of Keishito Prepared from Different Cinnamomi Cortex by Medical Students

Each of (a), (b), (c) shows an example of pattern by assessment of team and Fig. 2(d) show mean and mean value \pm a standard deviation, respectively.

皮 $(1.11 \pm 0.38 \%)>$ 桂通桂皮 $(0.54 \pm 0.13 \%) （ p=$ $0.003)$ ，桂通桂皮 $(0.54 \pm 0.13 \%)>$ 広南桂皮 $(0.04$ $\pm 0.01 \%) （ p=0.007 ） ，$ 精油成分は I 級桂皮 $(2.78$ $\pm 0.43 \mathrm{ml} / 50 \mathrm{~g})>$ 桂通桂皮 $(2.08 \pm 0.18 \mathrm{ml} / 50 \mathrm{~g})$ $(p=0.002)$ ，桂通桂皮 $(2.08 \pm 0.18 \mathrm{ml} / 50 \mathrm{~g})>$ 広南 桂皮 $(1.02 \pm 0.08 \mathrm{ml} / 50 \mathrm{~g}) \quad(p=0.00003)$ ，ケイヒ アルデヒド含有量は I 級桂皮 $(6.24 \pm 0.78 \%)>$ 桂 通桂皮 $(4.73 \pm 0.60 \%) \quad(p=0.006)$ ，桂通桂皮 $(4.73 \pm 0.60 \%)>$ 広南桂皮 $(2.39 \pm 0.63 \%) \quad(p=$ 0.0001) であり, Fig. 2(d)にみられるように, クマ リン，精油成分，ケイヒアルデヒドの含有量が多い I 級桂皮は味覚，嗅覚に対する好ましい刺激が強 く, 短時間で身体の温もりとして反応を感じ取っ た。同時に効果予測の評価が高かった.

2. 講義による関心度の向上と試験成績 実習 講義の前後における学生の漢方に対する関心度の変 化を Fig. 3 に示した。受講により興味がない学生 （21\%）が 9\%に減少した．漢方薬に対する関心度 を 116 名全員に 5 段階で評価させた結果，実習前 3.0 から実習後 3.4（ $p<0.01 ）$ と明らかに関心は高 くなった，将来，医師になったときに漢方施療，特 

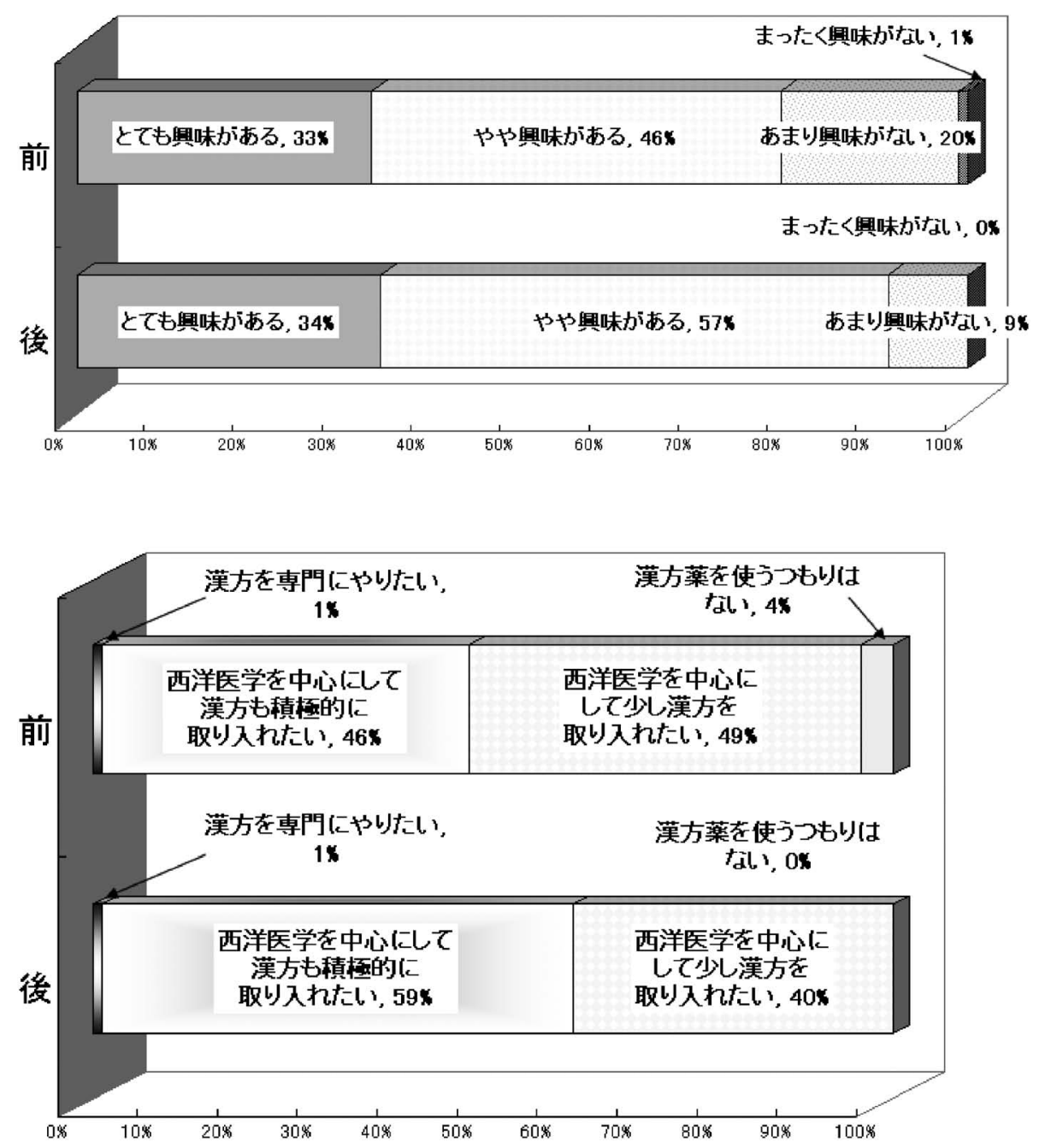

Fig. 3. A Questionnaire Survey before and after the Lecture: Change in the Interest in Kampo Medicine, and the Enthusiasm for Using Kampo Herbal Medicine as a Clinician

に漢方薬を使用するかという質問に対して，拒否す る学生は $4 \%$ から $0 \%$ に減少し, 積極的に取り入れ たいと答えた学生が実習前 $46 \%$ から実習後 $59 \%$ に 增えた。

漢方医学に対する関心度と試験成績の相関を調べ た. 気，血，水の概念やこれらの異常時に処方する 漢方薬名の記述を含む 100 点満点の漢方医学基礎試 験では，A と B のグループ間で成績の平均值（A； $79.4 \pm 1.4$, B ; 80.6 \pm 1.2$)$ に有意な差はなかった. しかし Aグループは関心度と成績に相関関係は認 められなかったが， B グループでは相関係数 0.400 $(p=0.0003)$ で関心の高い学生ほど得点が高かった.

A グループは試験を受けた時点で既に受講をして おり，関心度は受講していない B に比べて高くな つている（A；3.5, B；3.0, $p<0.01 ）$ 。この試験は 60 点を合格基準として問題が作成されており，A
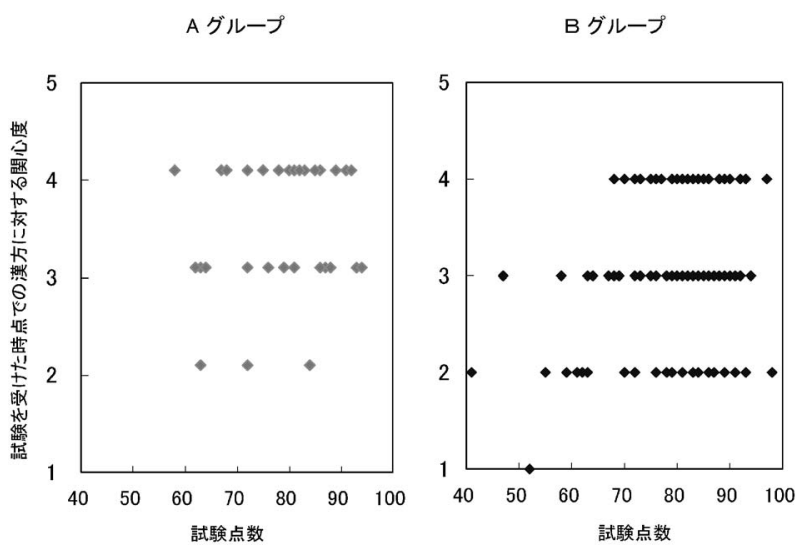

Fig. 4. Correlation between Interest Levels in Kampo Medicine and Kampo Exam Scores

グループは 58 点が 1 名 $(2.5 \%)$ であり $\mathrm{B}$ グルー プは 60 点未満 6 名 (7.9\%) で最低が 41 点と (Fig. 4), 基準点を下回る学生の割合に差がみられた. 


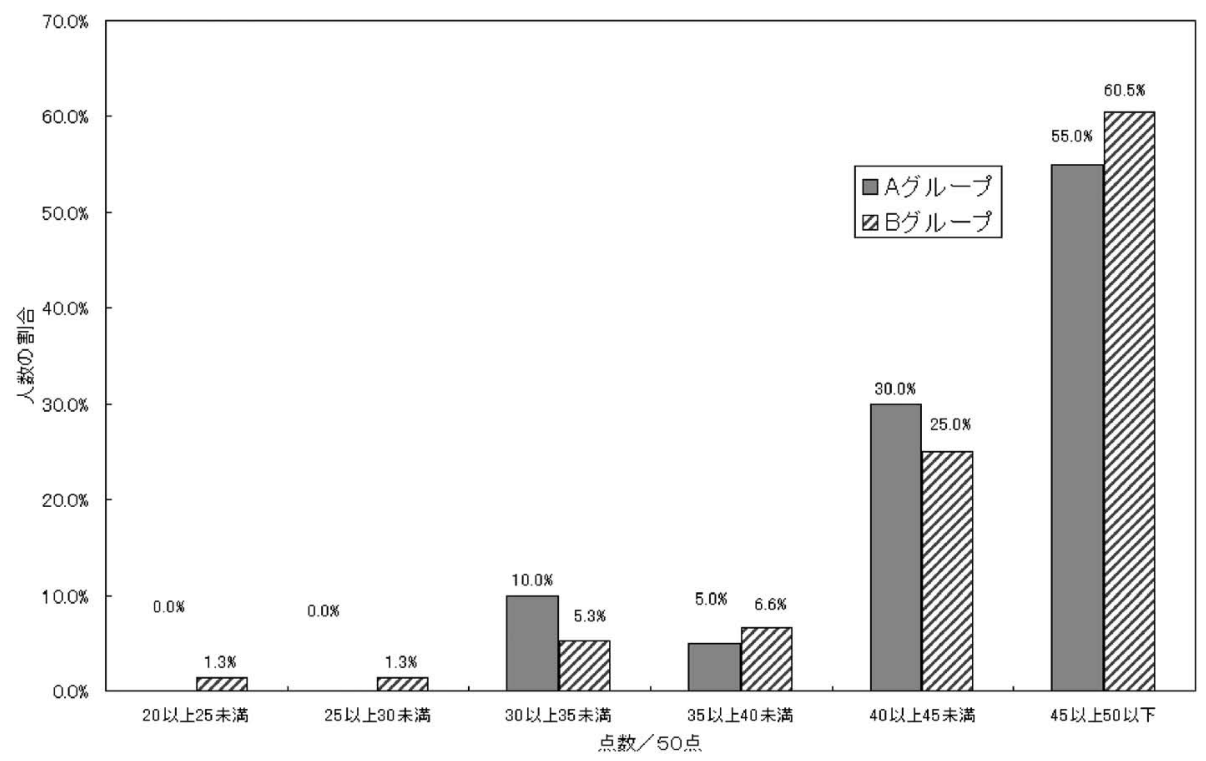

Fig. 5. Percentage of Correct Answers on the Pharmacology of Herbal Medicine and Effectiveness of Kampo Formula Exam: Comparison of A Group and B Group

問題構成において生薬と漢方薬の薬効薬理と副作 用や禁忌に関しては，100 点中 50 点の配分であっ た。この領域だけの成績を Fig. 5 に示した。A グ ループは全員が正答率 $60 \%$ 以上（平均正答率 $88 \%$ ） であるのに対し，Bグループは $60 \%$ 以下の学生が 2.6\%（平均正答率 $87 \%$ ） で，40\%から $100 \%$ と正 答率に幅が認められ関心度と得点において正の相関 が B グループにみられた（相関係数 $0.401, p=$ 0.0003).

\section{考察}

試験内容については漢方基礎理論で講義されてお り実習内容とは関係はない。 B グループは $40 \%$ か ら $100 \%$ の幅広い得点率を示し，関心度と正の相関 が認められた。実習後試験を受けた Aグループは 関心度が B グループより高く，全員が $60 \%$ 以上を 正解したが成績と関心度に相関が認められなかっ た。漢方に理解の低かった学生の関心度が実習によ り高められ，学習意欲を一定向上させた結果 $60 \%$ 以上の得点率を示したが，漢方に関心が高かった者 においては得点上変化を与えなかったと推測した。 チーム実習中に，お互いに教え合う行為が見受けら れたことから, 漢方に関心の低い学生の理解度を チームメンバーが引き上げたと推察され，初学者に 対するモチベーションの向上には効果があると考え られた。今後は既習者の知識や意欲に応じた実習内
容についても検討し，継続学習に向けたチーム型自 主学習について検討する.

桂枝湯の調製と服用による判定実習では，個人差 はあるものの辛味の指標成分であるクマリンの含有 量が高い I 級桂皮の辛味を察知し，含有量が低い広 南桂皮を甘いと評価した学生の感性と評価は誤って いない. 西洋医学の現場では漢方は主観性が強く, 個々の感性の違いから論理や客観的進歩が少ないと 捉えられがちで，学生においても漢方薬を捉えどこ ろのないものとし疑惑や不安を訴え，服用を望まな い者もあった。しかし漢方薬の感覚による評価が, 機器定量分析の結果と合致し薬効評価につながると 理解すると，積極的に手で触れる，匂う，味わうと いう行動が観察できた．客観的情報の提示は主観的 判断を確たるものとすることから，漢方教育におい ても有効な方法と考えられた，実習直前の認識調査 では，漢方は伝統があり（56.2\%）健康促進には適 すが $(49.1 \%)$ ，根拠に乏しく $(26.7 \%)$ 疑わしい $(10.3 \%)$ ．医師として漢方薬の処方をあまり希望し ない（59.5\%）と答えたが，実習直後は漢方に関心 を示し $(91.3 \%)$ ，五感を使い漢方生薬や人を観察 することは大切 $(72.3 \%)$ で国際医療にも漢方薬が 活用されると予測又は期待する $(63.7 \%)$. 治療に 役立つ $(83.4 \%)$ ので積極的に処方したい $(58.6 \%)$ ， 取り入れたい $(40.5 \%)$ と答え，治療薬として漢方 薬に関心を示した. 
漢方診断は，血液検査や機器を用いる客観的方法 でなく望診 (観察), 聞診 (聴覚, 嗅覚による患者 からの情報収集), 問診, 切診（脈や腹部の緊張度 などを手で触れて観察する）により非侵襲的であ る。患者の生活環境や心身に影響を及ぼす社会的背 景の情報も集約して，患者の生理生態系のひずみを 改善すべく処方薬を選択することから，オーダー メード医療として市民に期待される。しかし先進医 療が展開される 21 世紀のオーダーメード医療は, 患者個々への適正治療の提供は有効性や安全性の確 保が求められる。漢方では, 生薬の物性と薬性の確 認，コンプライアンスと薬効の両面を考慮した漢方 服用薬の調製，生薬植物は同時に食物として使用さ れているものもあることから，アレルゲンの調査な ど，医療薬学のさらなる展開が必要である.

日本の医学部教育は 20 世紀の終わりから急速な

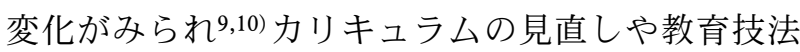
が検討されている. ${ }^{11)}$ 薬学の展開については 6 年制 薬剂師の育成にうかがえる通りであるが，2003 年 には実務実習モデル・コアカリキュラムにおいて倫 理性，ヒューマニズムを思索し，病態の理解や薬物 療法ができる臨床に秀でた薬剤師の養成が求められ ている. ${ }^{12)}$ 全国の薬学において客観的臨床能力試験 （OSCE）による評価が報告され ${ }^{13,14)}$ 保険薬局にお いても試行されるようになった。 ${ }^{15)}$ 現実，年齢によ る医療区分（高齢者医療）が施され，医師不足と医 師の多忙，医療経済の斜陽が訴えられる折から，义 タボリック健診のような疾病予防や健康管理に複数 職域の医療者の関与が既に求められている。医療薬 学の一部は医・薬両職域に必須の学問体系であると 推察でき，領域の特性を相互に検討すれば，医学生 と薬学生が共同参画するチーム型講義の展開も考え られた。

\section{REFERENCES}

1) Model core curricuram. In: Association of Japanese Medical Colledges, ed. A White Paper on the Medical School of Japan 2005., Assoc. Jpn. Med. Coll., 60-75 (2005) .

2) Watanabe K., Nishimura K., Ishige A., Gregory A. P., Aiso S., Kitajima M., Amano T., Med. Educ. (Jpn), 39, 125-129 (2008).

3) Sato Y., Kampo Med., 56, 29-34 (2005) .

4) Kita T., Kogure T., Yoshizaki H., "Textbook of Kampo Medicine for Students," by The Japan Society for Oriental Medicine, Nankodo Co., Ltd., Tokyo, 2007, pp. 1-93.

5) Hioki C., Takashima M., Tashiro S., Iyaku J., 34, 185-188 (1998) .

6) Hioki C., Yoshimoto K., Yoshida T., Clin Exp. Pharmacol, Physiol., 31, 614-619 (2004).

7) Thompson M. B., Schnider F. V., Haider P., Levine E. R., McMahon K. K., Perkowski C. L., Richards F., B., Med. Educ., 41, 250-257 (2007).

8) William T., Acad. Med., 76, 1171 (2007).

9) Kozu T., Kobe J. Med. Sci., 43, 216-225 (1998).

10) Onishi H., Yoshida I., Med. Teach., 26, 403408 (2004).

11) Kozu T., Acad. Med., 81, 1069-1075 (2006).

12) Conference on the curriculum for pharmaceutical education, Pharmaceutical Society of Japan, "Model Core Curriculum, Pharmaceutical Society of Japan" (2002).

13) Hanya M., Matsuba K., Matsui T., Jpn. J. Pharm. Health Care Sci., 32, 997-1008 (2006) .

14) Horibe S., Ohnishi N., Takara K., Yokoyama T., Jpn. J. Pharm. Health Care Sci., 30, 529535 (2004).

15) Tanaka N., Maruyama M., Amagai A., Satome K., Tomikawa E., Michiyama K., Kondo S., Tanaka H., Sato H., Yakugaku Zasshi, 128, 97-110 (2008). 